Research Article

\title{
Suppression of Stem-End Rot on Avocado Fruit Using Trichoderma spp. in the Central Highlands of Kenya
}

\author{
E. K. Wanjiku $\mathbb{D}^{1,2}$ J. W. Waceke, ${ }^{1}$ and J. N. Mbaka ${ }^{3}{ }^{3}$ \\ ${ }^{1}$ Department of Agriculture Science and Technology, Kenyatta University (KU), Nairobi, Kenya \\ ${ }^{2}$ Department of Animal Health and Production, School of Pure and Applied Sciences, Mount Kenya University, Thika, Kenya \\ ${ }^{3}$ Horticulture Research Institute, Kenya Agricultural and Livestock Research Organizations (KALRO), Ruiru, Kenya
}

Correspondence should be addressed to J. N. Mbaka; jesca.mbaka@kalro.org

Received 7 June 2020; Revised 12 February 2021; Accepted 24 February 2021; Published 5 March 2021

Academic Editor: Othmane Merah

Copyright ( $\odot 2021$ E. K. Wanjiku et al. This is an open access article distributed under the Creative Commons Attribution License, which permits unrestricted use, distribution, and reproduction in any medium, provided the original work is properly cited.

Demand for organic avocado fruits, together with stringent food safety standards in the global market, has made producers to use alternative, safe, and consumer-friendly strategies of controlling the postharvest fungal disease of avocado fruits. This study assessed the in vitro efficacy of Trichoderma spp. (T. atroviride, T. virens, T. asperellum, and T. harzianum) against isolated avocado stem-end rot (SER) fungal pathogens (Lasiodiplodia theobromae, Neofusicoccum parvum, Nectria pseudotrichia, and Fusarium solani) using a dual culture technique. The Trichoderma spp. were also evaluated singly on postharvest "Hass" avocado fruits. Spore suspension at $5 \times 10^{4} \mathrm{conidial} / \mathrm{ml}$ of the Trichoderma spp. was applied on the avocado fruits at three time points, twenty-four hours before the fungal pathogen (preinoculation), at the same time as the fungal pathogen (concurrent inoculation), and 24 hours after the fungal pathogen (postinoculation). In the in vitro study, T. atroviride showed the highest mycelial growth inhibition against $N$. parvum (48\%), N. pseudotrichia (55\%), and F. solani (32.95\%), while T. harzianum had the highest mycelial growth inhibition against $L$. theobromae. Trichoderma asperellum was the least effective in inhibiting the mycelial growth of all the pathogens. Similarly, T. virens showed the highest mycelial growth inhibition against N. pseudotrichia at $45 \%$ inhibition. On postharvest "Hass" fruits, T. atroviride showed the highest efficacy against N. parvum, N. pseudotrichia, and F. solani in all the applications. Trichoderma virens and T. harzianum were most effective against all the pathogens during postinoculation, while Lasiodiplodia theobromae was best controlled by T. virens, T. harzianum, and T. asperellum during postinoculation. Both T. atroviride and T. harzianum present a potential alternative to synthetic fungicides against postharvest diseases of avocado fruits, and further tests under field conditions to be done to validate their efficacy. The possibility of using Trichoderma spp. in the management of SER on avocado fruits at a commercial level should also be explored.

\section{Introduction}

Avocado (Persea americana Mill.) is one of the economically most important subtropical fruit crops worldwide and a major foreign exchange earner in Kenya $[1,2]$. In the year 2017, 300 MT of avocado fruits were exported from Kenya, contributing USD 50.5 million to the GDP [3]. Globally, avocado fruits are cultivated in a wide range of agroecological zones for both domestic and commercial purposes [4]. The fruit is valued worldwide for its high nutrition value due to the presence of monounsaturated fatty acids, several minerals (potassium, iron, and phosphorus), and vitamins (E, B, and C), as well as lipids and phytochemicals.
Moreover, the consumption of avocado fruit is associated with improved overall diet quality $[2,5]$.

Stem-end rot (SER) disease causes losses of avocado fruits in all avocado-growing regions of the world. The disease affects the fruits during marketing, storage, or even transit to the market [6]. Members of the Botryosphaeriaceae family (Diplodia mutila, D. pseudoseriata, D. seriata; Dothiorella iberica; Lasiodiplodia theobromae; and Neofusicoccum australe, $N$. nonquaesitum, and $N$. parvum) have mainly been associated with SER on avocado fruits. Other pathogens reported to cause the disease include Colletotrichum gloeosporioides or C. fructicola and Diaporthe foeniculacea Phomopsis perseae, Thyronectria pseudotrichia, 
Dothiorella aromatica, Pestalotiopsis versicolor, Rhizopus stolonifer, Fusarium sambucinum, and Fusarium solani [6-9]. In a previous study [10], L. theobromae, N. parvum, $N$. pseudothrichia, and F. solani pathogens were identified as the leading cause of SER of avocado fruits in Kenya.

Over the years, synthetic chemicals have successfully been used to control plant diseases, and they have a promising future. However, chemical residues on produce, nonbiodegradable toxins on fruits and soil, and the high cost of the chemicals have continued to be of significant concern [11]. Additionally, consumers are increasingly demanding reduced use of chemicals on produce. More so, food safety standards and organic food consumer organizations demand minimum detectable residues in produce [12]. Utilizing microbial fungicides, microbial antagonists, and biocontrol agents (yeast, bacteria, and antagonistic fungi) offers a potential alternative to synthetic fungicides in the management of postharvest diseases of fruits [13]. A biological control approach involves using microorganisms to reduce or maintain the postharvest fungal pathogens below economic loss [14].

Currently, several postharvest diseases of fruits can be controlled by either natural microbial antagonists or artificially introduced microbial antagonists [15]. Microbial antagonists present several advantages over synthetic fungicides. They are environmentally friendly, safer in application, have nontoxic residues, and are economical to produce [16]. Trichoderma spp. have been widely used during postharvest storage to protect fruits and vegetables of commercial importance such as chilli, mangoes, apples, bananas, strawberries, and tomatoes $[17,18]$. Trichoderma viride, T. harzianum, and T. koningii have demonstrated antagonistic activity against $L$. theobromae and Colletotrichum musae that cause postharvest crown rot disease complex of banana stored at room temperature and at cold storage [19]. Trichoderma harzianum has also been reported to control anthracnose in bananas, maintain postharvest fruit quality, and reduce natural fruit infections [20].

Substantial progress has been made towards biological control of postharvest diseases of avocado fruits $[16,21]$. However, no attempt has been made towards the biological control of postharvest disease of avocado fruits in Kenya. This study, therefore, investigated the antagonistic activity of the selected Trichoderma spp. against fungal pathogens associated with stem-end rots of avocado fruits in the central highlands of Kenya.

\section{Materials and Methods}

2.1. Source of the Isolates. Samples of "Hass" avocado fruits were obtained from orchards and local markets in Murang'a County in the central highlands of Kenya. The fruits were incubated at room temperature $\left(22^{\circ} \mathrm{C}-25^{\circ} \mathrm{C}\right)$ at Kenya Agricultural and Livestock Research Organization (KALRO), Kandara, for 7-14 days to allow development of stem-end rot disease. Fruits that displayed stem-end rot symptoms were cleaned with clean tap water, surface-sterilized by dipping in $75 \%$ ethanol for 3 minutes, and rinsed in distilled water. Small pieces of rotten tissues from the margins of the rot were aseptically isolated, inoculated on potato dextrose agar (PDA), and incubated at room temperature $\left(22-25^{\circ} \mathrm{C}\right)$ for 5 days. Pure cultures were obtained by subculturing the hyphal tips of the mycelia. The isolates were identified based on morphological and cultural characteristics and confirmed through molecular identification. Slant universal bottles were used to store the pure cultures in PDA at $4^{\circ} \mathrm{C}$. Four commonly isolated pathogens were used in this study.

2.2. Source of the Antagonists. Two commercial species spp. (T. asperellum and T. harzianum) and two locally acquired spp. (T. atroviride and T. virens) of Trichoderma were used in this study. Trichoderma harzianum was obtained from the biological fungicide TRIANUM P (T. harzianum Rifai strain T22, $1 \times 10^{9}$ colony-forming units (cfu)/gram of dry weight) from Koppert Biological Systems. Trichoderma asperellum was obtained from the biological fungicide MAZAO SUSTAIN (TRC900 $1.7 \times 10^{9} \mathrm{cfu} /$ gram of dry weight) from real IPM. Trichoderma atroviride (KRI) and $T$. virens (BMLT54P1) were obtained from the Department of Agriculture Science and Technology, Kenyatta University. Spore suspension was prepared by flooding fourteen-dayold pure cultures in PDA with sterile distilled water. A sterile wire loop was used to scrape off the conidia and bring them to suspension. The suspension was then filtered through a double-layer muslin cloth, and the collected filtrate was diluted serially to $1 \times 10^{5}$. A haemocytometer was used to adjust the spore concentration.

\subsection{Antagonistic Activity of Trichoderma spp. against Avocado Fruit Stem-End Rot Pathogens In Vitro}

2.3.1. Dual Culture Assay. The inhibitory activity of four Trichoderma spp., T. atroviride, T. virens, T. asperellum, and T. harzianum, against the four SER fungal pathogens, Lasiodiplodia theobromae, Neofusicoccum parvum, Nectria pseudotrichia, and Fusarium solani, was determined using the dual culture technique [8]. Sterile PDA was poured into Petri dishes $9 \mathrm{~cm}$ in diameter. The mycelial disc $(5 \mathrm{~mm}$ in diameter) from the edge of actively growing 7-day-old fungal colonies was placed at the edge of one side of the Petri dish. A mycelial disc $5 \mathrm{~mm}$ in diameter from an actively growing Trichoderma spp. culture was placed at the opposite edge of the Petri dish. The Petri dishes inoculated at one edge with a mycelial disc $5 \mathrm{~mm}$ in diameter of fungal pathogens served as control. Each treatment was replicated 6 times, and the Petri dishes were incubated at $25 \pm 2^{\circ} \mathrm{C}$. The mycelial growth of the test pathogen and of the antagonist was recorded. Percentage inhibition was calculated using the following formula as described by Rajendiran et al. [22]:

$$
\% \text { inhibition }=\frac{\mathrm{C}-\mathrm{T}}{\mathrm{C}} \times 100
$$


where C- mycelial growth of the pathogen in control and Tmycelial growth of the pathogen in the dual-culture plate.

\subsubsection{Effect of Trichoderma spp. against Stem-End Rot Fungal} Pathogens on Postharvest Avocado Fruits. Mature "Hass" avocado fruits were harvested from a farm in Murang'a County. Fruits with no apparent signs or symptoms of a disease and no physical damage were selected. The fruits were washed with running tap water and surface-sterilized by dipping them in $75 \%$ ethanol for 3 minutes. The fruits were then rinsed with distilled water and placed on sterilized trays to air-dry at room temperature.

The ability of Trichoderma species to suppress the development of SER on "Hass" avocado fruit was tested by adding each of the antagonists at three time points: (i) 24 hours before the fungal pathogen (preinoculation), (ii) at the same time as the fungal pathogen (concurrent inoculation), and (iii) 24 hours after the fungal pathogen (postinoculation) [8].

"Hass" avocado fruits were individually sprayed at the stem end with $50 \mu \mathrm{L}$ spore suspension $\left(5 \times 10^{5}\right.$ conidial $\left./ \mathrm{ml}\right)$ of the SER fungal pathogens (L. theobromae, N. parvum, $N$. pseudotrichia, and F. solani). A similar quantity of the antagonist was also used, and each of the treatments was
TABLE 1: Category scale used to rate the severity of SER development on the avocado fruits.

\begin{tabular}{lc}
\hline$\%$ Rot on avocado fruit & Grade \\
\hline No rot & 0 \\
$0-10 \%$ & 1 \\
$11-25 \%$ & 2 \\
$26-50 \%$ & 3 \\
$51-75 \%$ & 4 \\
$\geq 76 \%$ & 5 \\
\hline
\end{tabular}

replicated four times. The pathogens and the antagonist were applied on the fruits according to the schedule mentioned above. Fruits inoculated with each pathogen only and replicated four times served as the control. The experiment was conducted twice.

The inoculated avocado fruits were placed in sealed plastic containers (separate container for each fruit) at $25 \pm 2^{\circ} \mathrm{C}$ and incubated. Evaluation was conducted after 12 days by cutting the fruits lengthwise. A category scale of 0 to 5 was used to rate the severity of SER development on the avocado fruits; Table 1.

The percent disease index was calculated using the following formula as described by Lakshmi et al. [23]:

$$
\text { Percent disease index }(\mathrm{PDI})=\frac{\text { Sum of numerical ratings }}{\text { No. of fruits examined } \times \text { Maximum grade }} \times 100 \text {. }
$$

2.4. Data Analysis. The data obtained were recorded and tabulated in a spreadsheet. After that, the data were exported to Min Tab 17.0 software (Minitab, LLC). Descriptive statistics were generated upon which the data were expressed as mean \pm standard error of mean (SEM). One-way analysis of variance (ANOVA) was used to analyze the statistical significance of difference among treatment groups. Tukey's post hoc test was used for pairwise separation and comparison of means. The hypothesis for significance was tested at $p \leq 0.05$.

\section{Results}

3.1. Growth Inhibition of SER Pathogens by Trichoderma spp. in Dual Culture. All the Trichoderma species reduced the mycelial growth of the four (L. theobromae, N. parvum, N. pseudotrichia, and F. solani) avocado SER pathogens. The highest mycelial growth inhibition of $L$. theobromae was produced by $T$. harzianum $(54.57 \%)$ followed by T. atroviride (36.28\%). Trichoderma asperellum and T. virens were found to give the least growth inhibition $(29.88 \%$ and $29.27 \%$, respectively) against L. theobromae (Table 2). Trichoderma atroviride had the highest mycelial growth inhibition against $N$. parvum (48\%), N. pseudotrichia (55\%), and $F$. solani $(32.95 \%)$. Trichoderma atroviride $(p \leq 0.05)$ significantly inhibited the mycelial growth of $N$. parvum, $N$. pseudotrichia, and F. solani compared to the other antagonists. Trichoderma asperellum was found to be the least effective in inhibiting the mycelial growth of all the pathogens (L. theobromae (29.88\%), N. parvum (14.50\%), N. pseudotrichia (25\%), and F. solani (14\%) (Table 2)). Trichoderma virens inhibited the mycelial growth of all the pathogens; however, the highest inhibition was on N. pseudotrichia at $45 \%$ inhibition.

3.2. Effect of Trichoderma spp. on the Severity of SER on Postharvest "Hass" Avocado Fruits. All Trichoderma spp. inhibited the development of SER on avocado fruits. Fruits treated with T. asperellum in the three inoculations (preinoculation, concurrent inoculation, and postinoculation) remained free from SER caused by F. solani. Similarly, the severity of SER by $L$. theobromae was significantly different $(p \leq 0.05)$ reduced up to $10 \%, 7.5 \%$, and $5 \%$ in the three tests, respectively. During the three inoculation, T. asperellum reduced SER on avocado fruits by N. parvum up to $30 \%, 55 \%$, and $40 \%$, respectively. There was no development of SER by $N$. pseudotrichia during concurrent inoculation with $T$. asperellum; however, during preinoculation and postinoculation, SER severity reduced to $20 \%$ and 7.5 , respectively (Table 3 ).

All fruits remained free from SER due to N. parvum, $N$. pseudotrichia, and F. solani during concurrent and postinoculation with T. atroviride. Trichoderma atroviride did not inhibit development of SER on the fruits by L. theobromae during concurrent and postinoculation; however, during 
TABle 2: Antagonistic activity of Trichoderma spp. against SER fungal pathogens in vitro.

\begin{tabular}{lllll}
\hline \multirow{2}{*}{ Pathogens } & \multicolumn{3}{c}{ \% Mycelial growth inhibition } \\
& T. asperellum & T. harzianum & T. atroviride & T. virens \\
\hline L. theobromae & $29.88 \pm 3.94^{\mathrm{b}}$ & $54.57 \pm 1.35^{\mathrm{a}}$ & $36.28 \pm 1.35^{\mathrm{b}}$ & $29.27 \pm 1.93^{\mathrm{b}}$ \\
N. parvum & $14.50 \pm 2.22^{\mathrm{c}}$ & $37.50 \pm 2.50^{\mathrm{b}}$ & $49.00 \pm 1.00^{\mathrm{a}}$ & $35.50 \pm 1.26^{\mathrm{b}}$ \\
N. pseudotrichia & $25.00 \pm 0.58^{\mathrm{c}}$ & $42.50 \pm 2.50^{\mathrm{b}}$ & $55.00 \pm 2.89^{\mathrm{a}}$ & $45.00 \pm 3.79^{\mathrm{ab}}$ \\
F. solani & $14.00 \pm 4.76^{\mathrm{b}}$ & $15.40 \pm 1.78^{\mathrm{b}}$ & $25.00 \pm 3.00^{\mathrm{a}}$ & $21.00 \pm 1.00^{\mathrm{ab}}$ \\
\hline
\end{tabular}

Values are expressed as Mean \pm SEM for four replicates per group. Statistical comparisons were made within a row, and values with the same letter are not significantly different by one-way ANOVA followed by Tukey's post hoc test $(p \leq 0.05)$.

TABLE 3: Effect of Trichoderma spp. on the severity of SER on postharvest "Hass" avocado fruits.

\begin{tabular}{|c|c|c|c|c|}
\hline \multirow[t]{2}{*}{ Antagonist } & \multicolumn{4}{|c|}{$\begin{array}{l}\text { Disease severity index } \% \\
\text { pathogens }\end{array}$} \\
\hline & N. pseudotrichia & N. parvum & L. theobromae & F. solani \\
\hline $\begin{array}{l}\text { Preinoculation } \\
\text { T. asperellum } \\
\text { T. atroviride } \\
\text { T. harzianum } \\
\text { T. virens } \\
\end{array}$ & $\begin{array}{c}20.00 \pm 20.0^{\mathrm{b}} \\
0.00 \pm 0.00^{\mathrm{c}} \\
90.00 \pm 0.00^{\mathrm{a}} \\
0.00 \pm 0.00^{\mathrm{c}}\end{array}$ & $\begin{array}{c}30.00 \pm 10.00^{\mathrm{b}} \\
5.00 \pm 5.00^{\mathrm{c}} \\
30.00 \pm 15.0^{\mathrm{b}} \\
35.00 \pm 35.0^{\mathrm{a}} \\
\end{array}$ & $\begin{array}{c}10.00 \pm 10.0^{\mathrm{c}} \\
7.50 \pm 2.50^{\mathrm{c}} \\
42.50 \pm 2.50^{\mathrm{b}} \\
70.00 \pm 0.00^{\mathrm{a}}\end{array}$ & $\begin{array}{l}0.00 \pm 0.00^{\mathrm{b}} \\
7.50 \pm 2.50^{\mathrm{a}} \\
0.00 \pm 0.00^{\mathrm{b}} \\
0.00 \pm 0.00^{\mathrm{b}}\end{array}$ \\
\hline $\begin{array}{l}\text { Concurrent inoct } \\
\text { T. asperellum } \\
\text { T. atroviride } \\
\text { T. harzianum } \\
\text { T. virens }\end{array}$ & $\begin{array}{c}0.00 \pm 0.00^{\mathrm{a}} \\
0.00 \pm 0.00^{\mathrm{a}} \\
90.00 \pm 0.00^{\mathrm{a}} \\
7.50 \pm 7.50^{\mathrm{b}}\end{array}$ & $\begin{array}{c}55.00 \pm 0.00^{\mathrm{a}} \\
0.00 \pm 0.00^{\mathrm{c}} \\
17.50 \pm 2.50^{\mathrm{b}} \\
0.00 \pm 0.00^{\mathrm{c}}\end{array}$ & $\begin{array}{c}7.50 \pm 7.50^{\mathrm{d}} \\
100.00 \pm 0.00^{\mathrm{a}} \\
42.50 \pm 2.50^{\mathrm{c}} \\
70.00 \pm 0.00^{\mathrm{b}}\end{array}$ & $\begin{array}{l}0.00 \pm 0.00^{\mathrm{a}} \\
0.00 \pm 0.00^{\mathrm{a}} \\
0.00 \pm 0.00^{\mathrm{a}} \\
0.00 \pm 0.00^{\mathrm{a}}\end{array}$ \\
\hline $\begin{array}{l}\text { Postinoculation } \\
\text { T. asperellum } \\
\text { T. atroviride } \\
\text { T. harzianum } \\
\text { T. virens } \\
\text { Control }\end{array}$ & $\begin{array}{c}7.50 \pm 7.50^{\mathrm{a}} \\
0.00 \pm 0.00^{\mathrm{b}} \\
0.00 \pm 0.00^{\mathrm{b}} \\
0.00 \pm 0.00^{\mathrm{b}} \\
90.00 \pm 0.00^{\mathrm{a}}\end{array}$ & $\begin{array}{c}40.00 \pm 0.00^{\mathrm{a}} \\
0.00 \pm 0.00^{\mathrm{b}} \\
0.00 \pm 0.00^{\mathrm{b}} \\
0.00 \pm 0.00^{\mathrm{b}} \\
60.00 \pm 0.00^{\mathrm{a}}\end{array}$ & $\begin{array}{c}5.00 \pm 5.00^{\mathrm{a}} \\
100.00 \pm 0.00^{\mathrm{b}} \\
0.00 \pm 0.00^{\mathrm{b}} \\
0.00 \pm 0.00^{\mathrm{b}} \\
100.00 \pm 0.00^{\mathrm{a}}\end{array}$ & $\begin{array}{l}0.00 \pm 0.00^{\mathrm{a}} \\
0.00 \pm 0.00^{\mathrm{a}} \\
0.00 \pm 0.00^{\mathrm{a}} \\
0.00 \pm 0.00^{\mathrm{a}} \\
40.00 \pm 0.0^{\mathrm{b}}\end{array}$ \\
\hline
\end{tabular}

Values are expressed as Means \pm SEM for four avocado fruits per group. Means within respective columns followed by different lower-case superscripts are significantly different at $p \leq 0.05$.

preinoculation, the fruits remained free from SER development due to N. pseudotrichia. Similarly, the severity of SER due to $L$. theobromae, $N$. parvum, and F. solani was reduced to $5 \%, 7.5 \%$, and $7.5 \%$, respectively, during preinoculation with T. atroviride (Table 3 ).

During postinoculation with $T$. harzianum, no SER developed on the avocado fruits. Besides, during concurrent inoculation of $T$. harzianum with $N$. parvum, $N$. pseudotrichia, and F. solani, the fruits remained free from SER. Trichoderma harzianum did not inhibit development of SER on the avocado fruits due to L. theobromae during concurrent inoculation and $N$. pseudotrichia during preinoculation (Table 3).

All fruits remained free from SER when Trichoderma virens was inoculated 24 hours after the fungal pathogen. Similarly, during preinoculation, the avocado fruits remained free from SER due to N. pseudotrichia and F. solani, while in concurrent inoculation, no SER developed on the fruits due to N. parvum and F. solani. The severity of SER due to $L$. theobromae was reduced up to $42.5 \%$ in both preinoculation and concurrent inoculation with $T$. virens (Table 3).

Trichoderma atroviride was most effective in controlling the development of SER by N. parvum, N. pseudotrichia, and
F. solani in all treatments, while Trichoderma virens and T. harzianum were most effective during postinoculation (Table 3).

\section{Discussion}

The ability of $T$. harzianum to significantly inhibit the mycelial growth of $L$. theobromae reported in this study agreed with the study by Wijeratnam et al. [24] where T. harzianum was reported to effectively control L. theobromae that caused SER of papaya and mangoes in Sri Lanka. Similarly, Bhadra et al. [25] reported the greatest inhibition of $T$. harzianum against $L$. theobromae in concurrent inoculation. Moreover, T. harzianum has been reported to significantly reduce stem-end rot of Rambutan caused by L. theobromae [26].

In this study, T. atroviride was the most effective against F. solani as compared to T. asperellum, T. harzianum, and T. virens, corroborating results by Kumar et al. [27] who reported higher efficacy of $T$. atroviride against $F$. solani compared to T. harzianum. Rajendiran et al. [22] also reported strong antagonistic activity of $T$. atroviride against Fusarium species that caused postharvest rots of fruits. Trichoderma atroviride inhibited the mycelial growth of 
L. theobromae up $36.28 \%$, although the inhibition was lower than that of T. harzianum (54.57\%), and T. atroviride has been reported to effectively control $L$. theobromae that cause stem-end rot of mangoes [28]. Trichoderma virens inhibited the mycelia growth of $L$. theobromae corroborating report by Buensanteai and Athinuwat [29] where T. virens strain TVSUT10 inhibited the mycelia growth of $L$. theobromae causing SER of cassava by $53 \%$.

Trichoderma asperellum inhibited the mycelial growth of L. theobromae up to $29.88 \%$. Trichoderma asperellum strain NG-TI61 was previously reported not to have any antagonistic activity against $L$. theobromae in vitro. However, the conidia and culture filtrates of $T$. asperellum controlled the rot caused by L. theobromae on the banana fruits [30] corroborating results in this study.

Trichoderma atroviride stood out in the control of N. parvum, N. pseudotrichia, and F. solani, while T. harzianum performed better in the control of L. theobromae during the in vitro test and postharvest treatment of the avocado fruits. Similarly, studies conducted by Borges et al. [31] on biocontrol of teak canker caused by L. theobromae showed a positive correlation between the in vivo and in vitro studies. Trichoderma atroviride showed higher efficacy than $T$. harzianum against $L$. theobromae, $N$. parvum, and N. pseudotrichia during preinoculation. In the evaluation of biocontrol agents for grapevine pruning wound protection, Kotze et al. [32] reported that $T$. atroviride was more effective than T. harzianum against L. theobromae and N. parvum when it was applied before the pathogens corroborating results from this study. Similarly, Valenzuela et al. [8] reported high efficacy of T. atroviride against C. gleosporiodes when it was inoculated 24 hours before the pathogen. The results could suggest that the bioactivity nature of the T. atroviride against fungal pathogens is protective.

Trichoderma asperellum showed high efficacy against L. theobromae on postharvest avocado fruits. Contrary to what was expected in the in vitro test, $T$. asperellum displayed an inhibition percentage of $29 \%$. However, this is comparable to report by Borges et al. [28] in the in vivo test of $T$. asperellum against $L$. theobromae causing teak canker, where T. asperellum showed complete control of L. theobromae.

When the fungal pathogens were applied on postharvest avocado fruits 24 hours before the antagonists, T. asperellum, T. harzianum, and T. virens showed high efficacy against SER caused by the four fungal pathogens. Likewise, T. atroviride showed complete efficacy against $N$. parvum, N. parvum, N. pseudotrichia, and F. solani showing the ability of Trichoderma spp. to control the fungal pathogens even when they have established on the fruits.

\section{Conclusions}

Results from this study have demonstrated that Trichoderma spp. could be viable biological tools that can be used in the management of SER diseases of avocado fruits and they have the potential to replace the synthetic fungicides. The use of biological fungicides will go a long way in facilitating the avocado producers to produce high-quality avocado fruits free from toxic residues. However, there is a need to carry out field trials to validate the efficacy of the Trichoderma spp. and the possibility of using the species on a commercial scale.

\section{Data Availability}

The data used to support the findings of this study are included in the article.

\section{Conflicts of Interest}

The authors declare that there are no conflicts of interest regarding the publication of this paper.

\section{Acknowledgments}

The authors are grateful to the management of Kenya Agricultural and Livestock Research Organization (KALRO), Kandara, where this work was carried out. This research was funded by the author's personal finance.

\section{References}

[1] Horticultural Crops Directorate (HCD), Horticultural Crops Production Report, HCD, Nairobi, Kenya, 2016.

[2] B. A. Schaffer, B. N. Wolstenholme, and A. W. Whiley, The Avocado: Botany, Production and Uses, CABI, Nairobi, Kenya, 2013.

[3] Horticultural Crops Directorate (HCD), Horticultural Crops Production Report, HCD, Nairobi, Kenya, 2017.

[4] J. P. Bower and J. G. Cutting, "Avocado fruit development and ripening physiology," Horticultural Reviews, vol. 10, pp. 229-271, 1988.

[5] M. L. Dreher and A. J. Davenport, "Hass avocado composition and potential health effects," Critical Reviews in Food Science and Nutrition, vol. 53, no. 7, pp. 738-750, 2013.

[6] M. Twizeyimana, H. Förster, V. McDonald, D. H. Wang, J. E. Adaskaveg, and A. Eskalen, "Identification and pathogenicity of fungal pathogens associated with stem-end rot of avocado in California," Plant Disease, vol. 97, no. 12, pp. 1580-1584, 2013.

[7] J. M. Darvas, "Fungi associated with pre-and post-harvest diseases of avocado fruit at Westfalia Estate, South Africa," Phytophylactica, vol. 19, no. 1, pp. 83-86, 1987.

[8] N. L. Valenzuela, D. N. Angel, D. T. Ortiz, R. A. Rosas, C. F. O. García, and M. O. Santos, "Biological control of anthracnose by postharvest application of Trichoderma spp. on maradol papaya fruit," Biological Control, vol. 91, pp. 88-93, 2015.

[9] V. Guarnaccia, A. Vitale, G. Cirvilleri et al., "Characterisation and pathogenicity of fungal species associated with branch cankers and stem-end rot of avocado in Italy," European Journal of Plant Pathology, vol. 146, no. 4, pp. 963-976, 2016.

[10] E. K. Wanjiku, J. W. Waceke, B. W. Wanjala, and J. N. Mbaka, "Identification and pathogenicity of fungal pathogens associated with stem end rots of avocado fruits in Kenya," International Journal of Microbiology, vol. 2020, Article ID 4063697, 8 pages, 2020.

[11] K. Chandrashekara, S. Manivannan, and C. Mohan, "Biological control of plant diseases," Eco-friendly Innovative Approaches in Plant Disease Management, Springer, Berlin, 
Germany, 2012, https://www.researchgate.net/publication/ 233119112.

[12] X. Wang, F. Pacho, J. Liu, and R. Kajungiro, "Factors influencing organic food purchase intention in developing countries and the moderating role of knowledge," Sustainability, vol. 11, no. 1, p. 209, 2019.

[13] M. S. Ferramola, D. Benuzzi, V. Calvente et al., "The use of siderophores for improving the control of post-harvest diseases in stored fruits and vegetables," Microbial Pathogens and Strategies for Combating Them: Science: Technology and Education, pp. 1385-1394, Formatex Research Center Spain, Badajoz, Spain, 2013.

[14] S. Carmona-Hernandez, J. Reyes-Pérez, R. Chiquito-Contreras, G. Rincon-Enriquez, C. Cerdan-Cabrera, and L. Hernandez-Montiel, "Biocontrol of postharvest fruit fungal diseases by bacterial antagonists: a review," Agronomy, vol. 9, no. 3, p. 121, 2019.

[15] R. R. Sharma, D. Singh, and R. Singh, "Biological control of postharvest diseases of fruits and vegetables by microbial antagonists: a review," Biological Control, vol. 50, no. 3, pp. 205-221, 2009.

[16] A. S. Dukare, S. Paul, V. E. Nambi et al., "Exploitation of microbial antagonists for the control of postharvest diseases of fruits: a review," Critical Reviews in Food Science and $\mathrm{Nu}$ trition, vol. 59, no. 9, pp. 1498-1513, 2019.

[17] M. F. Begum, M. A. Rahman, and M. F. Alam, "Biological control of alternaria fruit rot of chili by Trichoderma Species under field conditions," Mycobiology, vol. 38, no. 2, pp. 113-117, 2010.

[18] M. Verma, S. K. Brar, R. D. Tyagi, R. Y. Surampalli, and J. R. Valéro, "Antagonistic fungi, Trichoderma spp.: panoply of biological control," Biochemical Engineering Journal, vol. 37, no. 1, pp. 1-20, 2007.

[19] E. M. Yahia, Post-harvest Biology and Technology of Tropical and Subtropical Fruits: Fundamental Issues, Elsevier, Amsterdam, Netherlands, 2011.

[20] G. Sangeetha, S. Usharani, and A. Muthukumar, "Biocontrol with Trichoderma species for the management of post-harvest crown rot of banana," Phytopathologia Mediterranea, vol. 48, no. 2, pp. 214-225, 2009.

[21] B. T. Demoz and L. Korsten, "Bacillus subtilis attachment, colonization, and survival on avocado flowers and its mode of action on stem-end rot pathogens," Biological Control, vol. 37, no. 1 , pp. 68-74, 2006.

[22] R. Rajendiran, D. Jegadeeshkumar, B. T. Sureshkumar, and T. Nisha, "In vitro assessment of antagonistic activity of Trichoderma viride against post-harvest pathogens," Journal of Agricultural Technology, vol. 6, no. 1, pp. 31-35, 2010.

[23] B. K. M. Lakshmi, P. N. Reddy, and R. D. Prasad, "Crossinfection potential of Colletotrichum gloeosporioides Penz. Isolates causing anthracnose in subtropical fruit crops," 2011.

[24] S. W. Wijeratnam, Y. Dharmatilaka, and D. Weerasinghe, "Host specificity of Colletotrichum gloeosporioides and Botryodiplodia theobromae isolates from mango, papaya and rambutan and their response to Trichoderma harzianum," in Proceedings of the Conference on International Research on Food Security, Natural Resource Management and Rural Development, University of Hohenheim, Northern Thailand, October 2008.

[25] M. Bhadra, A. Khair, M. A. Hossain, and M. M. Sikder, "Efficacy of Trichoderma spp. and fungicides against Lasiodiplodia theobromae," Bangladesh Journal of Scientific and Industrial Research, vol. 49, no. 2, pp. 125-130, 2014.
[26] O. Galsurker, S. Diskin, D. Maurer, O. Feygenberg, and N. Alkan, "Fruit stem-end rot," Horticulturae, vol. 4, no. 4, p. 50,2018

[27] R. Kumar, S. K. Singh, A. Kumari, A. Kumar, and S. Yadav, "In vitro evaluation of various bio-control agents against Fusarium solani isolated from Papaya (Carica papaya L.)," Int. J. Curr. Microbiol. App. Sci, vol. 6, no. 4, pp. 40-50, 2017.

[28] R. Bui, B. Sinha, P. S. Devi, R. Salam, K. Dinesh, and T. Chakma, "In vitro studies on efficacy of some plant extracts and biocontrol agents against Lasiodiplodia theobromae and Lasiodiplodia pseudotheobromae," International Journal of Current Microbiology and Applied Sciences, vol. 7, no. 07, pp. 448-457, 2018.

[29] N. Buensanteai and D. Athinuwat, "The antagonistic activity of Trichoderma virens strain TvSUT10 against cassava stem rot in Thailand," African Journal of Biotechnology, vol. 11, no. 84, pp. 14996-15001, 2012.

[30] A. Adebesin, C. Odebode, and A. Ayodele, "Control of postharvest rots of banana fruits by conidia and culture filtrates of Trichoderma asperellum," Journal of Plant Protection Research, vol. 49, no. 3, pp. 302-308, 2009.

[31] R. C. F. Borges, E. Marques, M. A. Macedo, I. Martins, J. G. da Silva Filho, and S. C. M. de. Mello, "Biocontrol of teak canker caused by Lasiodiplodia theobromae," Revista Árvore, vol. 42, no. 3, 2018.

[32] C. Kotze, J. Van Niekerk, L. Mostert, F. Halleen, and P. Fourie, "Evaluation of biocontrol agents for grapevine pruning wound protection against trunk pathogen infection," Phytopathologia Mediterranea, vol. 50, pp. S247-S263, 2011. 